COLLEGE OF AGRICULTURE

AGRICULTURAL EXPERIMENT STATION

BERKELEY, CALIFORNIA

\title{
STOCK POISONING PLANTS OF CALIFORNIA
}

BY

HARVEY MONROE HALL AND HARRY S. YATES

BULLETIN No. 249

Berkeley, Cal., March, 1915

UNIVERSITY OF CALIFORNIA PRESS

BERKELEY 
Benjamin Ide Wheeler, President of the University.

\section{EXPERIMENT STATION STAFF}

\section{Heads of Divisions}

Thomas Fonsyth Hunt, Director.

Eugene W. Hilgard, Agricultural Chemistry (Emeritus).

Edward J. Wickson, Horticulture.

Herbert J. Webber, Director Citrus Experiment Statiou; Plant Breeding:

Hubert E. Van Norman, Vice-Director; Dairy Management.

William A. Setchell, Botany.

Myer E. JAF'A, Nutrition.

Robert H. Loughridge, Soil Chemistry and Physies (Emeritus).

Charles W. Woodworth, Entomology.

Ralph E. Smith, Plant Pathology.

J. Ецiот Согт, Citriculture.

John W. Gilmore, Agronomy.

Charles F. Shaw, Soil Technology.

JoHN W. GReGG, Landscape Gardening and Floriculture.

Frederic T. Bioletti, Viticulture and Enology.

Warren T. Clarke, Agricultural Extension.

JoHn S. Burd, Agricultural Chemistry.

Charles B. Lipman, Soil Chemistry and Bacteriology.

Clarence M. Haring, Veterinary Science and Bacteriology.

Ernest B. Babcock, Genetics.

Gordon H. True, Animal Husbandry.

James T. Barrett, Plant Pathology.

Fritz W. Woll, Animal Nutrition.

A. V. Stubenrauch, Pomology.

WALter Mulford, Forestry.

W. P. Kelley, Agricultural Chemistry.

William G. Hummel, Agricultural Education.

- Leon M. Davis, Dairy Industry.

John E. Dougherty, Poultry Husbandry.

Frank Adams, Irrigation Practice.

David N. Morgan, Assistant to the Director.

Mrs. D. L. BunNeLL, Librarian. 


\section{STOCK POISONING PLANTS OF CALIFORNIA}

BY HARVEY MONROE HALL AND HARRY S. YATES

\section{INTRODUCTION}

Although much remains to be learned concerning the poisoning of stock by plants in California the subject is of such importance that it seems wise to place before the stockmen and veterinarians of the state a synopsis of our present knowledge concerning these matters. In preparing this publication the aim has been to adhere very closely to established facts and principles rather than to discuss mere theories as to the causes of poisoning and proposed remedies. The ability to recognize poisonous plants and to distinguish them from harmless ones is of the greatest importance to practical stockmen, since by the application of this knowledge they will be able to keep their animals away from infested areas during the seasons of greatest danger. The descriptions and illustrations here given, as well as the discussions regarding distribution and habitat, should be of value in this connection.

\section{POPULAR TREATMENT OF POISONED ANIMALS}

The prevalent theory that poisoned animals should be kept moving is, in most cases, entirely wrong. On the contrary they should ordinarily be kept as quiet as possible, for the high pulse and rapid breathing, which usually follows plant poisoning, indicate a high state of excitement and this would be only aggravated by forced exercise. The only exception is when the poison exerts a depressing action on the heart and drowsiness sets in. In this case heart action should be increased, preferably through the administration of stimulants, such as whisky, ammonia, etc. Cattle when down should always be urged to assume the position of normal repose, i.e., resting on the breast bone. In case the ground is sloping the head should be up hill.

The practice of indiscriminately bleeding all animals showing symptoms of plant poisoning is of very doubtful value. It is useful only for the purpose of relieving the blood pressure and should never be resorted to if the heart action is weak. At best, bleeding lowers the vitality and affords only temporary relief. Present-day veterinarians are rapidly learning to substitute better methods for this relic of mediaeval medical practice. 
Melted lard and other fatty substances are often administered with beneficial results, and are especially valuable where other remedies are not available. These substances act as mild laxatives, thus enabling the system to eliminate poisonous matter, and at the same time serve to coat the walls of the alimentary tract and so tend to check absorption of the poison.

Soda is useful for the purpose of neutralizing acid poison but should not be administered if the stomach is already alkaline. Similarly the administration of vinegar, which is an acid, will be found beneficial in case the stomach contents show an alkaline reaction.

Bloat sometimes occurs as a secondary effect in plant poisoning. It may be reduced by standing the animal in such a position that the front feet are on a much higher plane than the rear feet, and tying a stick in the mouth like a bit to keep the jaws wide apart. As a last resort the animal may be relieved by means of a trocar or sharp knife as in other cases of bloat, provided the attendant is familiar with the procedure in this operation.

\section{PERMANGANATE OF POTASH AS AN ANTIDOTE}

More valuable by far than any of the above mentioned remedies is permanganate of potash. This chemical was especially recommended by Chesnut and Wilcox in their pioneer work on the stockpoisoning plants of Montana, and though more recent investigations indicate that it is not so effective as they then supposed, it is nevertheless a very valuable remedy, especially in cases where other and more specific antidotes are unknown.

Permanganate of potash, through its strong oxidizing action, attacks and breaks down most of the plant poisons. This oxidizing action is accelerated when the substance to be treated is acid in reaction. The contents of the stomachs of animals are very often only slightly acid, or in some cases may be even alkaline. Because of this fact it has been found advantageous to administer with the permanganate some other chemical which will increase the acidity. Sulfate of aluminum is used for this purpose since it is easily administered and is not so dangerous as the acids themselves. Permanganate of potash and sulfate of aluminum are quite inexpensive and are carried by all druggists.

In practice it has been found that best results are obtained when equal amounts of the two chemicals are used. The table below indicates the dosage for adult animals. For younger stock the amount should be somewhat reduced. 
Sheep and hogs

5 to 10 grains

5 to 10 grains
Horses

15 to 20 grains

15 to 20 grains
Cattle

30 to 50 grains

30 to 50 grains

The thoroughly pulverized chemicals are first dissolved in a pint to a quart of pure hot water and after cooling, the solution is administered as a drench. Great care must be exercised to insure a complete solution of the permanganate since any undissolved crystals may lodge in the mucous membrane of the mouth and throat and set up a serious irritation. The powder should be added to the water, the solution thoroughly stirred and allowed to settle for several minutes, the solution is then drawn off and any dregs which may remain in the bottom discarded. All organic matter, such as sugar, syrup, etc., must be kept out of the liquid and the water used should not be strongly alkaline.

For practical purposes large quantities of the antidote are sometimes made up and kept on hand. The objection to this practice is that the solution loses its power in time. A better method is to have the chemicals put up in powder form, each powder containing the requisite quantity for one animal. These may then be dissolved as needed.

In the application of this remedy the time element is most important. The permanganate is only effective on the poison while it is in the stomach; it has no effect after the poison has once entered the blood; hence the importance of administering the antidote at the earliest possible moment. In case the animal gives evidence of improvement after the first dose but again lapses into its previous condition the dose should be repeated.

\section{WATER HEMLOCK (Cicuta species)}

(Umbelliferae, or Parsley Family)

Names.-Water hemlock is sometimes called cowbane, poison parsnip, and wild parsnip. The true parsnips, as well as the cow parsnip, are related but quite different plants and are not dangerous to stock.

Description.-Water hemlock is a tall branching perennial herb, two to five feet high. The smooth hollow stems grow erect from a stout enlarged rootstock or from a cluster of rootstocks which are characterized by having a central hollow space divided by cross partitions into chambers, as is shown in figure 1 . This structure of the underground parts is very characteristic and if they are examined there will be little chance of mistaking any other plant for water hemlock. The leaves are doubly pinnately compound or sometimes simply pinnate; the edges of the leaflets are finely toothed. The small white flowers are borne in compound umbels and are followed by the numerous seed-like fruits, which resemble those of parsley. 
The only plants likely to be confused with water hemlock and possessing similarly chambered rootstocks are Coelopleurum maritimum, a rare plant of our northwest coast, and water parsnip (Sium cicutaefolium). The former is probably itself poisonous. The water parsnip, which never causes poisoning, differs from most species of water hemlock in its leaves, which are simply pinnate. However, one species of water hemlock also has leaves of this type and since the other characters used to distinguish these two groups of plants are highly technical it is advisable to submit doubtful specimens to a botanist for determination.

Distribution and habitat.-Although the several species of water hemlock are widely distributed in western North America they are all limited to moist or even wet ground. The California species grow mostly in marshes, often with tule, and in low wet meadows, especially along the streams. Sometimes they form narrow borders along mountain streams and around springs.

Poisonous characters.-All parts of the plant are poisonous because of the presence of a resin known as cicutoxin. The resin is particularly abundant in the rootstocks, of which it is said that a piece the size of a walnut contains enough poison to kill a cow. These underground parts are likely to be trampled out of the soft wet ground in which they grow and are then readily eaten. Animals are also sometimes poisoned through feeding on hay containing portions of water hemlock. Experiments carried on at the University of Washington indicate that, in one species at least, a larger quantity of the toxic substance is contained in the plant in the fall and winter months. Cattle, horses, and sheep all eat the plant.

Symptoms.-Symptoms of severe pain appear very soon; sometimes within fifteen minutes. The first indication of poisoning is a tendency to run away from the herd. Within a very short time there appear symptoms of cerebral frenzy along with involuntary muscular movements resembling those made by animals suffering from colic. There is frequently an increase in the flow of saliva. The pupils are often widely dilated. Respiration is labored and somewhat irregular; the pulse is wiry and intermittent. As the attack proceeds the muscular spasms become more and more severe and cerebral excitement increases until the animal appears to be unconscious and finally dies. The duration of the attack is usually very brief; sometimes death ensues within fifteen minutes but more often in two or three hours. In very mild cases the animal may live for a day or two. In cattle and sheep there may be bloating in mild cases. The poison has a corrosive effect upon the walls of the stomach, which become dark in color and much softened. Frequently there may be found pieces of 


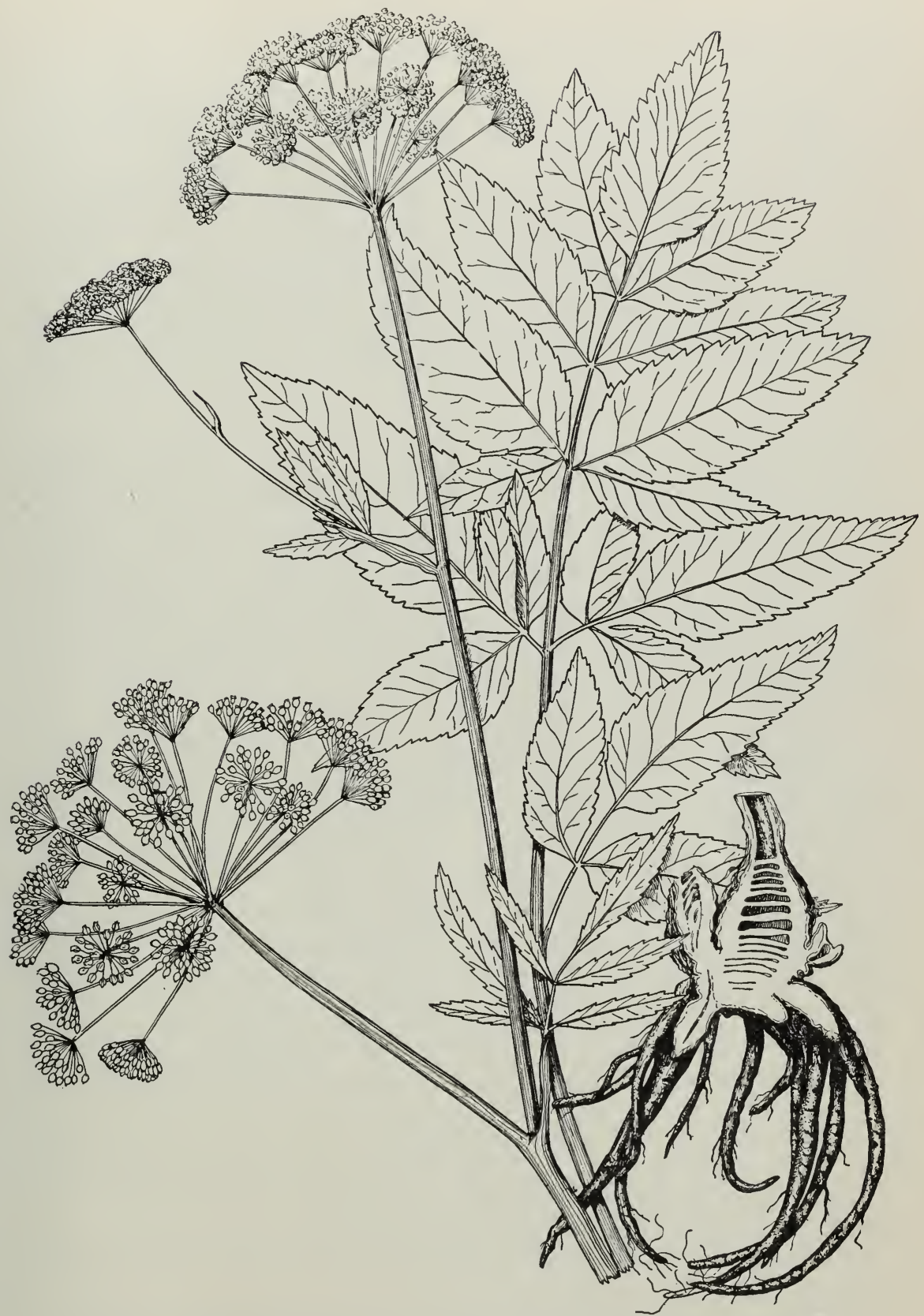

Fig. 1. Water hemlock (Cicuta occidentalis). One-half natural size. Water hemlock grows in moist or wet ground. The underground portion contains most of the poison. Cattle, horses, and sheep are poisoned by water hemlock. The leaves are sometimes much narrower than here figured. 
the characteristic rootstock of water hemlock in which case there is no doubt as to the plant responsible.

Remedies.-The toxic substance contained in water hemlock is so rapid in its action that any remedy must be administered very promptly. If the symptoms are already apparent morphine may be injected hypodermically to allay the pain. The dose is $1 \frac{1}{2}$ grains for sheep, 3 to 7 grains for horses and 3 to 10 grains for cattle. Melted lard or any fatty substance might also be effective if given soon after the first symptoms appear. It is doubtful whether permanganate of potash would be effective in case of poisoning by water hemlock. An emetic followed by a cathartic would perhaps be more effective, the object being to eliminate the poison from the stomach as soon as possible.

Preventive measures.-As in the case of other poisonous plants the first step to be taken in prevention is to become acquainted with the plant so that it may be distinguished from harmless species of the parsley family. Since water hemlock is restricted to wet places this at once eliminates a great many plants which might be taken for it. The most characteristic feature of the plant is the structure of the underground parts, seen especially well in a longitudinal section of the rootstock (see figure on page 223).

Since the plants often occur only in rather circumscribed areas and then usually not in great number, eradication by digging will be found feasible in many cases. If dug out the plants should not be left where stock can reach them. If eradication by digging is not feasible stock should be fenced away from areas on which water hemlock grows. It not infrequently happens that the weed is much less plentiful than one would think from the number of animals poisoned, for the reason that it grows only along some stream or around a pond where they come to drink. In such cases a comparatively small amount of digging or fencing will remove the danger. Stock should, in any case, be kept away from marshy areas where it is known to occur.

\section{SUMMARY}

Water hemlock occurs throughout the state in wet ground and along streams, but not in sandy or stony soils.

All parts of the plant are poisonous, but the roots and rootstocks are most virulent.

Owing to the rapidity with which the poison takes effect, remedies are of little avail. Morphine to allay the pain and an emetic followed by a cathartic are among the suggested remedies. 
By means of fencing or herding, stock should be kept away from areas infested by this plant.

Eradication by digging will be found feasible in many cases.

\section{DEATII CAMAS (Zygadenus venenosus)}

(Liliaceae, or Lily Family)

Names.-This plant is also known as poison camas, poison sego lily, mystery-grass, wild onion, and lobelia, but none of these names are properly applied to it. Squirrel-food and hog potato are additional local names.

Description.-Death camas is an erect herb, one to two feet high, with slender grass-like leaves from near the base and bearing later in the season a terminal oblong cluster of small white flowers. It grows from a roundish bulb one-half to one and one-half inches thick, covered with thin brown coats; although similar in appearance to that of the wild onion, this bulb lacks the peculiar onion odor. The lower leaves are six to sixteen inches long by less than one-half inch wide, parallel-veined, and often mistaken for grass leaves but without the ligule and joint which in all grasses mark the junction between blade and sheath. The individual flowers, scarcely over one-eighth inch across, are borne on short branches of the cluster, the sepals and petals are three each and similar; there are six protruding stamens, and a three-celled ovary which matures into a three-lobed seed-pod.

The true camas, or quamash (Camassia quamash and C. leichtlinii), the bulbs of which are eaten by the Indians, is readily distinguished from death camas by its larger bulb and larger blue flowers. It grows in very wet places, especially in the mountains.

Distribution and habitat.-This plant grows in all of the Pacific States and is especially plentiful in the northern part of California. In the middle and southern parts of the state it is restricted to the mountain meadows and even there it is seldom sufficiently plentiful to constitute a menace.

Of special interest to stockmen is the fact that death camas is very exacting in the matter of soil and moisture, so that one familiar with its requirements can predict almost to a certainty whether or not it will be found in a given meadow the conditions of which are known. It always grows in moist soils, but never in marshy or wet places. In dry meadows it is therefore restricted to the swales and ravines, in wet meadows to the higher and better drained portions but it never grows along the dry meadow borders. Aside from meadows, the plants are often found along depressions in the hills where the moisture is near the surface but these belts are usually too narrow to be of much importance. 
Poisonous characters.-All parts of the plant are poisonous to sheep but the leaves cause the most trouble since they are eaten along with grass during spring months. The bulbs are dangerous only after rains, since at other times it is almost impossible for sheep to pull them out of the ground. The seeds are said to produce poisoning when the mature plants are eut and fed with hay from natural meadows. Hogs are seldom if ever poisoned by death camas but on the contrary seem to thrive on it; this has given to the bulbs the name of "hog potato." So far as we have been able to learn, horses and cows universally refuse to eat death camas.

Symptoms.-The symptoms are remarkably uniform and characteristic so that stockmen should be able to recognize cases of poisoning by this plant. According to Chesnut and Wilcox, the first signs of poisoning are a certain uneasiness and irregularity in the movements of the sheep. As these symptoms become more pronounced they are accompanied by spasms and rapid breathing. An increased flow of saliva and regurgitation through the mouth and nostrils nearly always take place. The later symptoms include complete motor paralysis, combined with exceedingly rapid and shallow breathing and a frequent weak pulse. Death may ensue in from one to twelve hours, depending upon the amount eaten. It often happens that a sheep will become paralyzed and lie quietly on its side for some hours, after which it will slowly recover, but there is little hope for an animal that has been down for twenty-four hours or longer. The lungs become much congested and while the brain may also show slight congestion it has no lesions.

Remedies.-Permanganate of potash and aluminum sulfate administered as described on page 220 has been recommended as an effective antidote in cases of poisoning by death camas. Chesnut also suggests, as an equally good remedy, caffein diuretin, given hypodermically or even through the mouth. Caffein diuretin is not earried in stock by most druggists but could be ordered in advance by stockmen where animals are likely to be subject to poisoning by death camas. This remedy is not so easily administered as permanganate of potash.

Preventive measures.-The first step to be taken in prevention is to become thoroughly acquainted with the plant, in order that it may be distinguished from harmless species. Its habit of lurking in the meadows where it is eaten along with grasses makes its recognition by stockmen a matter of prime importance. During the flowering period it may be known at a glance by the characteristic cluster of white flowers but its leaves so closely simulate those of certain grasses that it is not so easily detected in its younger stages. However, the 


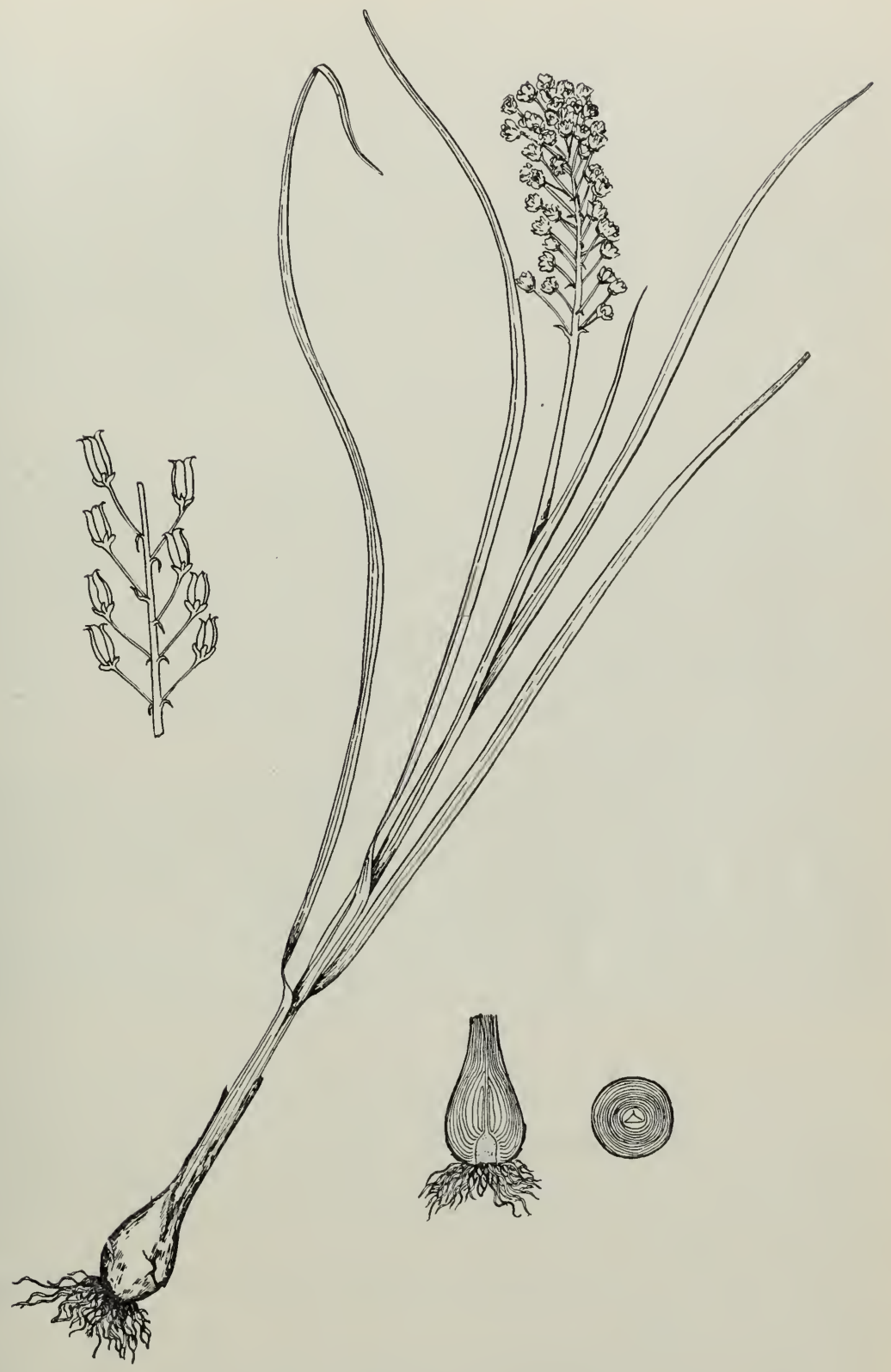

Fig. 2. Death camas (Zygadenus venenosus). One-half natural size. A plant of moist but not wet soil, occurring chiefly in northern California. The leaves are the parts usually eaten. Sheep are the animals most often poisoned. 
entire absence of ligule and joint between blade and sheath is a reliable distinguishing character since these are present in all grass leaves. In case of doubt the underground parts should be examined. No California grass grows from true bulbs. Other members of the lily family might be mistaken for death camas but not many of them grow in meadows, except certain species of Brodiaea and these may be distinguished by the solid "bulb" without concentric layers.

Eradication of death camas from the range is rarely practicable. Where it grows at all the plants are usually so numerous and their uprooting so laborious that this method is far too expensive. Eradication is feasible only where the species grows in narrow strips, as along shallow ravines in the mountains.

A better policy and one which is more generally followed is to fence or herd stock away from infested areas until all danger of poisoning is over. The most dangerous period is in the early spring when the grass is beginning to grow. The death camas sends up its leaves somewhat ahead of the grass but they also dry up and become harmless before the grass fully matures. Before admitting animals to pastures where the plant grows one should make a careful examination to see that no considerable number of the plants are still in a green or growing condition.

In the valley meadows of northern California and in Owens Valley the plants have usually passed their dangerous condition by the first or middle of July. On the mountain ranges it may be as late as August, in southern California as early as June. But it must be remembered that the date of maturity will vary with season as well as with altitude, slope, etc. and that the condition of the plants can therefore be determined only by a personal examination.

\section{SUMMARY}

Death camas is common in the meadows of northern California where it grows in moist situations but not in wet or boggy soil.

While all parts of the plant produce poisoning the leaves are the part usually eaten.

Permanganate of potash and caffein diuretin have been recommended as remedies.

By means of proper fencing or herding sheep should be kept away from this plant in the springtime and until its green parts have dried up.

It is important that stockmen should be able to distinguish death camas from grasses and from other harmless plants. 


\section{LARKSPURS (Delphinium species)}

(Ranunculaceae, or Buttercup Family)

Names.-Larkspurs are seldom known by any other name, although they are sometimes called "cow poison," or "poison weed." Robust leafy species, three to six feet high, are here referred to as tall larkspurs (Delphinium glaucum, D. californicum, and their allies). Under low larkspur we include species which do not ordinarily exceed two feet in height and are leafy only towards the base ( $D$. parryi, $D$. decorum, etc.).

Description.-The tall larkspurs produce many erect stems forming conspicuous leafy clumps becoming three to six feet high. The low larkspurs

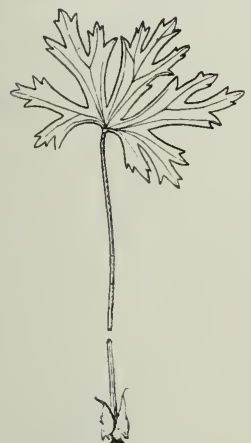

Fig. 3. Leaf of Geranium showing stipules. One-third natural size. have solitary or few stems and are much less conspicuous. In all species the leaves are alternate and palmately divided into mostly toothed or deeply cut segments. The flowers of the dangerous kinds are some shade of blue or lavender and are borne in terminal erect racemes. The individual flower has a very characteristic shape owing to the spur-like backward development of the upper sepal, as shown in figure 4 . The numerous seeds are borne in dry, three-pointed pods one-fourth to three-fourths of an inch long.

Wild geranium is sometimes mistaken for larkspur when examined before the flowers appear, but it can always be distinguished by the fact that the leaves bear two small appendages known as stipules at the base of the petiole or leaf-stem (see fig. 3), while in larkspur the stipules are not present. Aconite, or monkshood, is sometimes confused with tall larkspur with which it often grows, but the upper leaves are more numerous and nearly sessile, and the flowers are conspicuously hooded instead of spurred.

Distribution and habitat.-In California the tall larkspurs are restricted to moist meadows, gulches, and borders of springs or ponds in the northern part of the state and the Sierra Nevada. It is especially plentiful along rivulets and moist ravines leading into mountain meadows. Species of low larkspur also occur in the same districts but inhabit only open hillsides, sparsely forested areas, and similar situations and are not sufficiently abundant to be a serious menace. In the Coast Ranges, however, and especially in their southern portions, certain species of low larkspur are rather abundant and serious losses from poisoning are reported. The plants here grow on open hillsides and in openings in the chaparral. Here their green tufts of basal leaves, appearing in the early spring, before other feed is plentiful, are very tempting to livestock. 
Poisonous characters.-Probably all parts of the plant are poisonous except the flowers. The roots are rarely eaten and so are of little importance. The time of greatest danger from these plants is while the young leaves and stems are growing, before the flowers appear. After the flowering period the plant of the low larkspur very soon withers and dries up, becoming unattractive to stock, while in the tall larkspur the leaves lose their poisonous properties as the plant matures. It is therefore of the utmost importance for stockmen to become familiar with the leaf and stem characters so that they may recognize the plant before the flowers appear. The seeds are more poisonous than the leaves but are seldom eaten in sufficient quantity to cause trouble. Larkspurs are particularly dangerous during seasons when there is a scarcity of feed either through overstocking or drought. Under such conditions larkspur may become the most conspicuous form of vegetation on the range and attract animals accordingly.

Cattle and horses are the animals usually killed by eating these plants. It seems probable that sheep are never injured by them.

Symptoms.-Usually the earlier symptoms of larkspur poisoning resemble those of death camas very closely. In both cases there is a marked stiffness of the muscles and a certain irregularity in the gait. These symptoms become more pronounced and in larkspur poisoning the animal soon falls, often very suddenly, "the legs appearing to crumple up under it." The skin is sensitive to the touch and the muscles of the sides quiver. The special senses, however, are not impaired. The later stages of poisoning by larkspur are characterized by violent kicking and attempts to rise but "it can hardly be said that the poison produces convulsions" (Marsh). This activity on the part of the animal constitutes a distinguishing feature between poisoning by death camas and larkspur. In cases of poisoning by death camas the animal usually lies in a stupefied condition during the later stages, convulsions being entirely absent.

Autopsies of animals poisoned by larkspur show inflammation of the stomach, small intestine, and windpipe, and congestion of the surface blood vessels. The kidneys are usually much congested.

Remedies.-In mild cases the animal will recover if congestion is relieved by the simple expedient of turning the body so that the head will be higher than the other parts. The animal should then be allowed to rest quietly. The following formula has been used as a subcutaneous injection with very beneficial results and is especially recommended by Marsh to those accustomed to the use of a hypodermic syringe. 


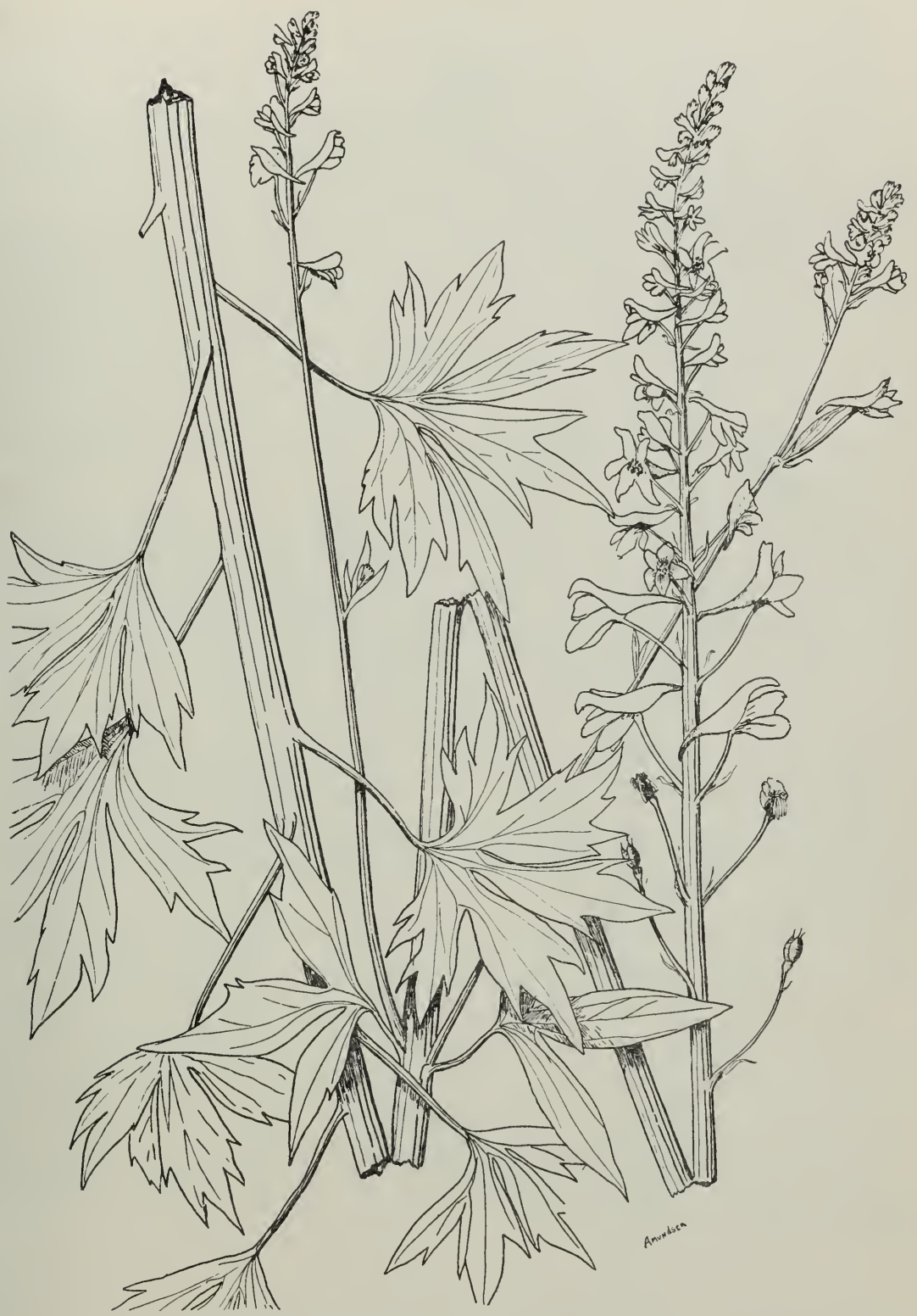

Fig. 4. Tall mountain larkspur (Delphinium glaucum). One-half natural size. A type of our tall larkspurs, which are plants of moist ground in the mountains. Low larkspurs grow in more open places. All parts of the plant except the flowers are poisonous. 
Physostigmin salicylate, one grain.

Pilocarpin hydrochlorid, two grains.

Strychnin sulfate, one-half grain.

These quantities are for an animal weighing five hundred or six hundred pounds. This remedy relieves constipation and stimulates respiration. The dose should not be repeated.

Preventive measures.-Eradication of larkspurs from the range is not practicable, since the plants are usually so numerous where they occur that uprooting would be far too expensive. It is feasible only in small pastures or when the plants form dense stands on small areas. A better policy is to fence or herd stock away from the infested areas until the flowering period has passed. This procedure will occasion little loss since the forage on the area may be utilized later in the season.

It should be remembered that small amounts of larkspur are not fatal and that if other feed is plentiful there is no danger in admitting animals to ranges where it grows. Ranges where cattle and horses could not be grazed may be profitably turned over to sheep, since they are seldom if ever injured by larkspur.

\section{Summary}

The young leaves and stems are usually the parts of larkspur plants which cause poisoning.

Perhaps all of our California species of larkspur are poisonous but many of them do not grow in sufficient abundance to constitute a menace.

It is important that stockmen should distinguish between larkspur and similar plants, especially aconite and wild geranium.

By means of proper fencing or herding, stock should be kept away from these plants until the green parts have dried up.

Sheep may be safely admitted to ranges where severe losses would result from the grazing of cattle or horses.

Poisoned animals should be permitted to remain as quiet as possible and the body should be turned so that the head is higher than the other parts.

MILKWEEDS (Asclepias species)

(Asclepiadaceae, or Milkweed Family)

Names.-These plants are generally known by the name of milkweed. Descriptive terms are added to designate the various species, since there are nine kinds more or less common in California. Among 


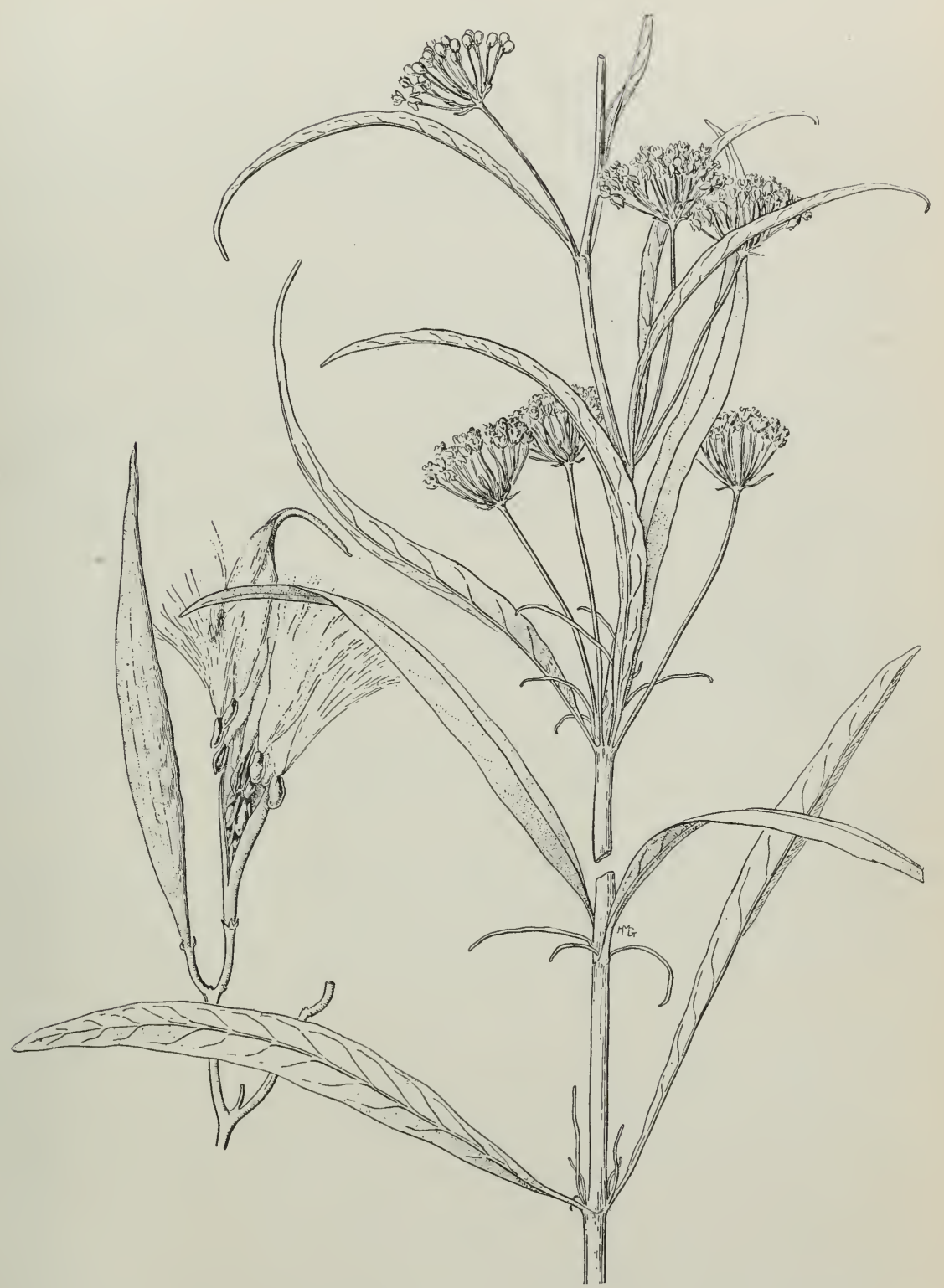

Fig. 5. Narrow-leaf milkweed (Asclepias mexicana). Other milkweeds have broader leaves. Milkweeds grow in dry soil. The leaves and stems contain the poison. Sheep are the animals usually poisoned by milkweeds. 
the most important of these are the narrow-leaf milkweed (Asclepias mexicana), the woolly-pod milkweed ( $A$. eriocarpa) and, in the mountains, the showy milkweed ( $A$. speciosa). Not all plants with a milky juice are milkweeds in the true sense. For example, both sow thistle and prickly lettuce have a milky juice, yet neither is dangerous to stock; both have the leaves alternately arranged on the stem and are thus distinguished at a glance from the true milkweeds.

Description.-The milkweeds are erect herbs with a milky juice and grow one and one-half to five feet high from thick perennial roots. The leaves are opposite or in whorls of three or four and both leaves and stems are usually more or less woolly. In narrow-leaf milkweed, the species figured on page 233, the leaves are smooth (without wool) and narrower than in most of our other species. The flowers are borne in umbels variously arranged near the summit of the stem; they are usually some shade of pink or white and are quite characteristic in shape. The parts of the flower are in fives. The fruit is a pod containing numerous seeds, each of which has a silky tuft of hairs at the end.

Distribution and habitat.-Milkweeds are inhabitants of dry and poor soil, often growing in dry stony stream beds, along waysides or railway embankments, or on exposed gravelly slopes. They range throughout the state at low altitudes and one species, the showy milkweed, is found in the Sierra Nevada up to seven thousand feet altitude, growing in the drier parts of meadows where it is perhaps never eaten.

Poisonous characters.-The leaves and stems of the milkweed are poisonous. So far as we are able to learn, horses and cattle seldom eat the plants, but sheep are sometimes poisoned. When feeding free on the range even sheep are in but little danger of milkweed poisoning, but when driven for long distances over territory where food and water are scarce they are often attracted to these rather succulent herbs. Late summer and autumn are the seasons of greatest danger.

Symptoms.-No detailed study has been made of the symptoms of milkweed poisoning but the following description has been drawn from the observations of shepherds. Soon after eating, the sheep falls behind the rest of the band, then stops and walks backward a short distance. This is said to be the most characteristic symptom. The effect of the poison seems to be to stupefy the animal, for even the wildest will not run away when approached. The sheep may stand still for some time, occasionally lying down and rising again. The muscles of the sides and flanks tremble, the eyes are glassy, and there is usually some frothing at the mouth. The duration of the symptoms is from one to six hours. 
Remedies.-It is probable that the permanganate of potash remedy would be effective and is worthy of trial. So far as we can find, it has not been used in cases of milkweed poisoning.

Preventive measures.-No especial precautions are required against these plants while sheep are grazing at will on a range. During long drives it is advisable to send a man ahead to locate large patches of the plants in order that the band may be driven around them and to cut down any scattering milkweeds along the route. These simple methods, already employed by many practical sheepmen, should be more generally followed, since their universal use would practically eliminate milkweed from the list of dangerous plants.

\section{SUMmary}

Milkweeds are common on the dry hills and plains throughout the state.

The leaves and stems are poisonous.

Milkweeds are especially dangerous to sheep when driven across dry barren country.

Permanganate of potash will probably be found an effective remedy.

Milkweeds growing on a route taken by sheep across country should be cut down or the band should be driven around them.

\section{LUPINES (Lupinus species) \\ (Leguminosae, or Pea Family)}

Names.-In California the various species of lupine are sometimes known as blue pea, wild pea, pea vine, and even wild bean, but all of these names are erroneous. Although we have many pea-like and bean-like native plants, the lupines may be distinguished from most of these by the leaf characters as pointed out below.

Description.-The lupines are annual and perennial herbs or low shrubs belonging to the pea family. The leaves are long stemmed and divided into from four to fifteen leaflets radiating from the summit of the common leafstalk. The plant illustrated is fairly typical of all our species, any of which should be recognized from the figure. The flowers are borne in long terminal racemes or spikes and are quite showy taken together, though singly they are rather small. In different species the flowers may be blue, white, yellow, or pink; in general structure they resemble those of the common bean or pea. The fruit is a pod similar to that of the pea and contains two or more small seeds.

Distribution and habitat.-No portion of California is entirely free from lupines except the cultivated districts, the swamps, and some portions of the desert area. Nearly all cases of poisoning, 
however, occur in the northern part of the state where the plants are used to some extent for hay.

Poisonous characters.-Several of our species of lupine are known to be poisonous to stock and it is quite probable that many more will be found to be more or less injurious. As far as present investigations go the seeds are the only part of the plant positively known to be poisonous, although the green herbage, as in other members of the same family cause bloat if eaten in large quantities, especially when it is wet or when eaten by animals just in from a dry range or when hot or very hungry. Lupines are often fed as hay with no ill effects if gathered either before the seeds have matured or after they have fallen from the pod. Sometimes stock have been poisoned by lupine fed under apparently the same conditions as in preceding years when no ill effects followed. But in every case of poisoning it was found that the hay had been cut after the poisonous principle had formed in the seeds and before these had fully matured and shattered out. Lupines, therefore, should never be fed nor cut for hay while mature or nearly mature seed is in the pod, unless it has been positively proved that the species used is not poisonous. Even when not in seed great caution should be exercised in the use of lupine hay.

Symptoms.-The symptoms caused by lupine poisoning are rather definite and have given rise to the term lupinosis. In Europe two forms of lupine poisoning are recognized, an acute and a chronic form. In the United States, so far, only the acute form has been recognized.

From the beginning there is an acute cerebral congestion accompanied by great mental excitement. The animals appear crazed and rush about in all directions butting into each other and other objects. This first stage of frenzy is followed by a second characterized by irregularity of movement, violent spasms, and falling fits, increasing in severity until finally collapse occurs. When the animal is unable to stand, convulsions follow each other at short intervals. Death usually occurs within one-half to one and one-half hours after the first symptoms, although animals may sometimes linger on for a day or so. During the attack the pulse is strong and irregular, there is often frothing at the mouth, the flow of urine is increased and this is sometimes bloody. The lungs and cerebral membranes are congested and in more violent cases small blood vessels are found ruptured in various parts of the body.

Remedies.-The permanganate of potash remedy is recommended for cases of poisoning by lupine, but it must be administered very early in the attack to be effective. By the rapidity with which the symptoms appear it is evident that enough of the toxic substance 


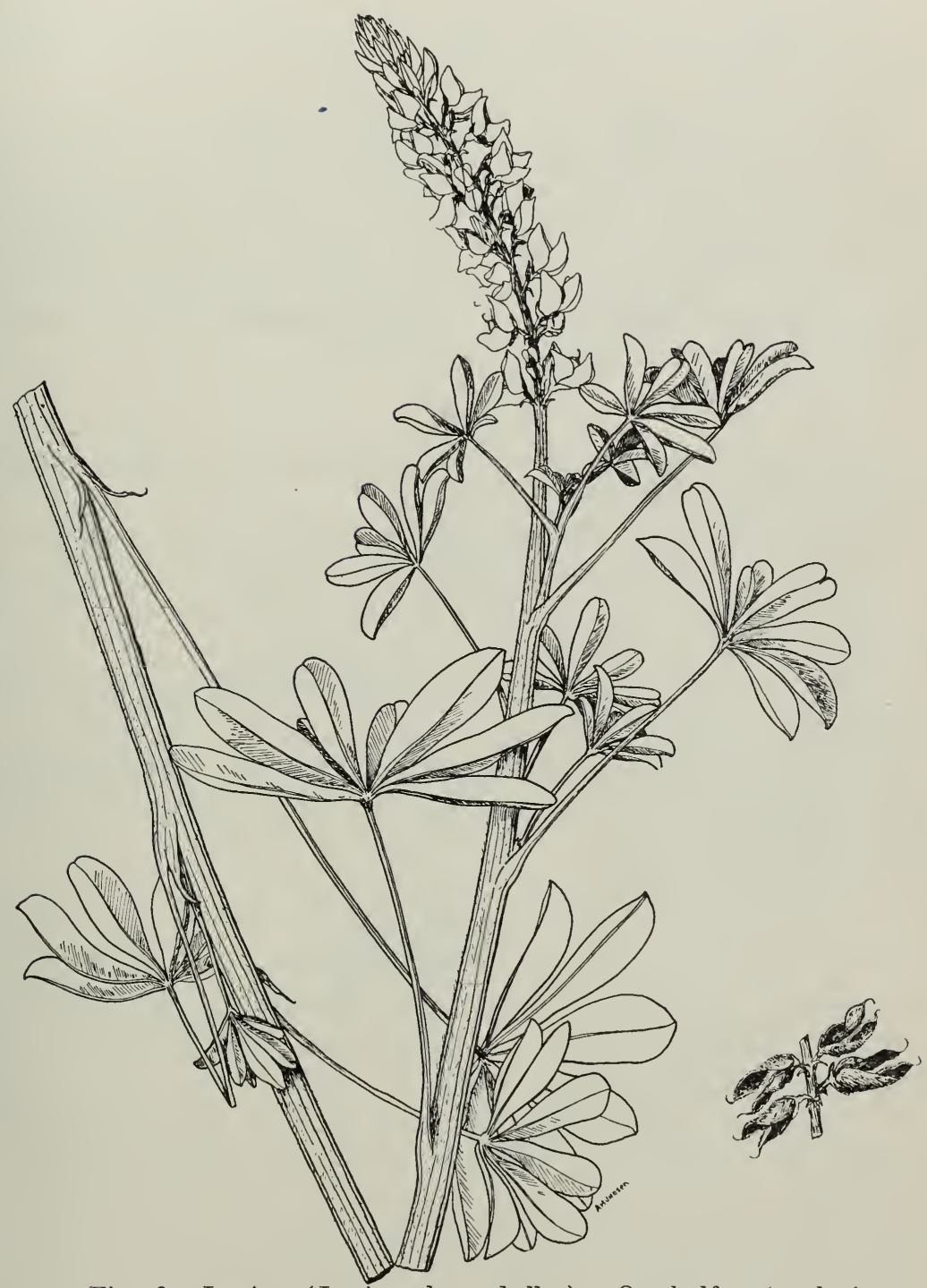

Fig. 6. Lupine (Lupinus leucophyllus). One-half natural size. Lupines occur throughout the state except in swamps. Most cases of poisoning occur in northern California. Only the seeds are poisonous. All classes of stock are poisoned. 
to cause death enters the general circulation very soon after the seed has been eaten. Acids are also recommended for lupine poisoning. For this purpose acetic acid or very dilute sulfuric acid is suitable. Since vinegar contains acetic acid its use would be beneficial. Alkalies should be avoided.

Preventive measures.-The eradication of lupine is impractical but much can be accomplished by keeping stock away from these plants when they are maturing their seed, and hay containing lupine seed should be discarded. As a prevention against bloat animals should not be turned into a field of lupines which are wet or while the animals are exceedingly hungry. Animals gradually become immune to this bloating effect of lupine.

\section{Summary}

Lupines are very abundant in California and are often cut for hay in the northern part of the state.

The seeds are the most dangerous part of the plant though bloat may be caused by feeding upon the green herbage.

Lupines should never be fed to stock while the pods contain mature or nearly mature seed.

The recommended remedies include permanganate of potash and weak acids.

To prevent bloat stock should not be allowed to feed upon green lupine when wet or if the animals are very hungry or are not accustomed to the range.

\section{LOCO-WEEDS (Astragalus species)}

(Leguminosae, or Pea Family)

Names.-The term "loco-weed" is applied to any species of Astragalus suspected of causing the loco disease. The sorts with bladdery-inflated pods are often known as rattle weeds. Some of the most dangerous species belong to the section of Astragalus known as Aragallus, considered by some botanists to be a distinct genus.

Description.-The loco-weeds are annual and perennial herbs belonging to the pea family, with odd-pinnate leaves. The purple, white, or pale-yellow flowers resemble those of the common bean in shape but are of smaller size and are borne in crowded racemes, spikes, or heads. The fruit is probably the most characteristic feature of these plants; it is a pod containing from two to many small seeds and is commonly turgid or inflated and bladder-like. There are many species of Astragalus in California but all are quite similar in structure, so there should be little difficulty in recognizing any of them after a study of the figure of Astragalus hornii on page 239; it must be remembered, however, that they vary much in size and in the shape of the pod. 


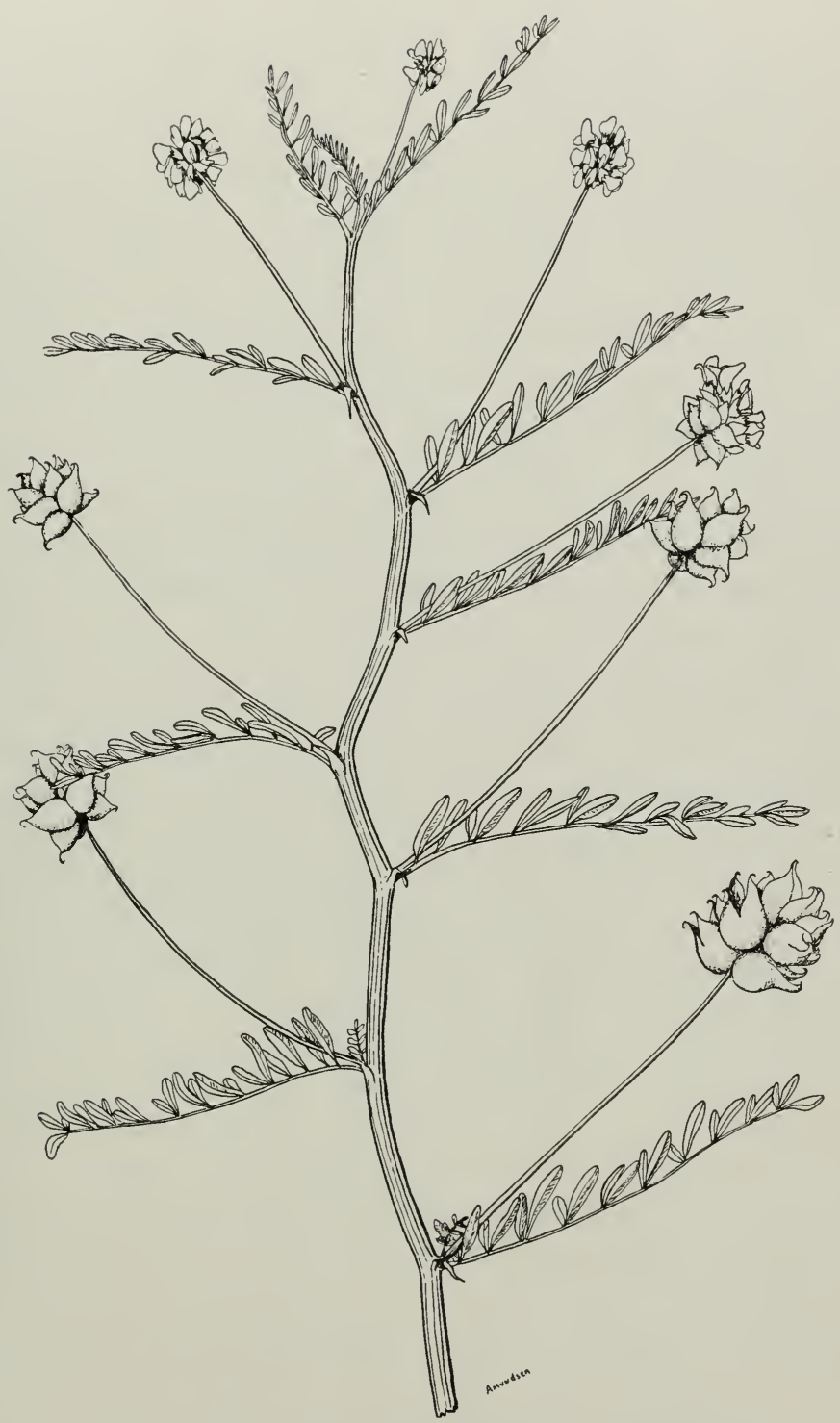

Fig. 7. Loco-weed (Astragalus hornii). One-half natural size. One type of our California species of loco-weeds, which are found throughout the state except in moist places. Sheep and horses are the animals commonly affected; cattle rarely. 
Distribution and habitat.-These plants are much too common in all of our western states, ranging from sea level nearly to the summits of our highest peaks. They do not grow in meadows but often inhabit meadow borders and are abundant on many of the plains and upland ranges.

Poisonous characters.-Notwithstanding the large amount of study that has been given to the loco disease, the principle which causes it is as yet unknown. For a time the injurious effect was thought to be due to barium but recent investigations have overthrown this theory. We are unable to give a list of the species of Astragalus which are harmful, so that for the present practically all of them must be regarded with suspicion. Cases of loco poisoning are much less common in California than in the Rocky Mountain states and it is possible that only a few of the kinds growing here are really injurious.

The poisonous substance, whatever it may be, acts as a slow poison, affecting primarily the nervous system and resembling in its effect that of drug habits in man rather than of the other plant poisons we have been considering. A peculiarity of the disease is that while animals do not at first readily eat the weed, yet having once become addicted to the habit, they will seek the loco-weed and feed upon it to the partial or complete exclusion of other plants. This "loco-habit" is often formed through imitating other animals or because of the scarcity of better food. Owners of stock in infested districts should therefore appreciate the importance of keeping animals well supplied with proper food and of immediately removing from the band or herd any individual that has acquired the habit. There seems to be some relation between the loco habit and the salting of stock. Chesnut states that sheep are more likely to form the loco habit when deprived of salt and that the eating of alkali seems to create a perverted appetite which leads animals to feed upon loco-weeds.

Horses and sheep are the animals most commonly addicted to the loco habit. Cattle eat the weed but rarely. Colts and lambs are far more likely to acquire the habit than are adult horses and sheep.

Symptoms.-Usually the first symptom of loco poisoning is a change in the general condition of the animal. It becomes stupid, is prone to wander away from the herd, and becomes emaciated, dejected, and untidy in appearance. The derangement of the nervous system makes itself evident in the incoördination of the muscular movements or through errors in judgment of the size and shape of objects. Irregularity in gait is noted and the animal drags its feet more or less, this being particularly noticeable in the hind legs. The 
muscular incoördination may first appear simply in the peculiarly extended or otherwise unnatural position in which the animal carries its head. Sometimes the animal becomes frightened from no apparent reason. Locoed horses used for draft or driving purposes frequently run away or indulge in spells of kicking without apparent reason. The sight and also the hearing may be affected, especially in acute cases. Horses lose the power of locomotion to a large degree during the later stages of the disease and will remain for long periods upon a small area of ground, seldom or never lying down and finally die of starvation.

In post mortem examination of locoed animals accumulations of coagulated serum in a gelatinous form are found in various parts of the body, particularly about the heart and in the cavity of the spinal column. The nervous system is more fully supplied with blood than when the animal is in a normal condition. The walls of the stomach are frequently inflamed and it is common to find ulcers in the pyloric end of the stomach of horses and in the fourth stomach of eattle and sheep.

Remedies.-At present no specific antidote is known for loco poisoning. In experimental work carried on in Colorado, by Dr. C. Dwight Marsh of the United States Department of Agriculture, and his associates, it was found possible to bring most animals out of the locoed condition if they were worth enough to warrant a rather extended course of treatment. The following directions are based on Dr. Marsh's results. (See Farmers' Bulletin 380.)

Many animals, during the early stages of the disease, can be cured by simply taking them away from the loco-weed and feeding them upon nutritious food. It is very important that this should have laxative properties, as locoed animals are always constipated. Green alfalfa is especially suitable, or oil meal may be mixed with the grain in case this is being fed. It is sometimes desirable to give epsom salts to relieve this constipated condition, the dose for cattle being about one pound, for calves two ounces, for horses eight ounces, and for full-grown sheep four ounces. These doses should be given as a drench and varied according to the size and condition of the individual. It is usually not necessary to repeat the dose many times if the feed is of a laxative character.

To relieve the nervous condition, Fowler's solution gives the best result in the case of horses. This is given, usually for a month, in daily doses of four to six drams with the grain or in drinking water. Strychnin is recommended for cattle. It should be given hypodermically in very small doses of three-twentieths to four-twentieths 
of a grain, continuing for about thirty days. Emphasis should be placed upon the importance of giving only small doses of strychnin as locoed animals are easily killed by the ordinary amounts administered for other diseases. In the case of sheep it will usually be the best policy to simply remove them from the band as soon as they show symptoms of loco poisoning and feed them upon nutritious food until fattened for market. Any animals which do not respond to this treatment after a reasonable time may as well be killed, as their only value is for the pelt.

Preventive measures.-Though it may be impossible to keep stock away from loco-weeds altogether, an effort should be made to keep at least young animals off a range where the poisonous kinds are known to grow, especially where there is a shortage of other feed. Animals addicted to the habit should be immediately removed from the band and placed in a pasture free from loco-weed or fattened for market. In the case of horses, although they may be kept away from loco-weed and appear to completely recover, they will sometimes show the effect of the loco-weed in various vicious habits, such as kicking or running away without apparent cause.

It will often be found practicable to eradicate these plants from the range. Since they are usually rather scattered or only in small patches, it takes much less labor than might be expected to clear them from a pasture. If the plants are cut off just below the crown of buds they will not grow again. It is advisable to kill them while in flower so that they will not mature the season's crop of seeds. The seeds live for several years and do not all germinate in any one season, so the area will have to be gone over a number of times before the weed is completely killed out.

\section{SUMmary}

Loco-weeds belong to a genus of plants very common in California, but cases of poisoning are rare, perhaps because most species are not injurious, or because they are harmful only under certain unusual conditions.

Eating of loco-weeds is a habit formed especially by young animals, and by adults when other food is scarce. The habit is learned by one animal from another.

Locoed animals should be immediately segregated and supplied with nutritious food of a laxative nature.

Fowler's solution for horses, and strychnin for cattle is recommended. 
Eradication of loco-weed from the range is sometimes practicable.

Special attention is called to Farmers' Bulletin 380 for further information.

\section{POISONOUS PLANTS OF MINOR IMPORTANCE}

In addition to the foregoing species there is a considerable list of California plants which may, under certain conditions, be more or less dangerous to domestic animals. Some of these are seldom eaten, because of their repulsive taste or smell; others grow in districts where stock rarely graze; and still others are poisonous for only short periods, or the poison is not sufficiently virulent to cause death. From this list, the following may be selected as of greatest importance.

Sorghum, Kafir Corn, and Johnson-grass (Andropogon species). Grass Family.-These well known agricultural plants are not native to California, but since under unusual conditions they may become very poisonous to stock and because of their great importance to the farmers of the state, they are considered in this place. Hot dry weather which arrests the growth, seems to favor the formation of prussic acid, which is a deadly poison. Stunted plants should therefore not be fed to stock. Young sorghum contains more poison than do the older plants and hence it is best not to pasture sorghum until it has nearly reached maturity. The prussic acid is said to disappear in drying so that when eured the plants may be fed with but little danger of poisoning. However, all plants belonging to the sorghum group should be fed with caution to animals which have fasted for some tịme.

Prussic acid exerts a depressing effect on the heart. The symptoms are drowsiness, twitching of the muscles, numbness of the limbs, a staggering gait, and weakness so that the animal is unable to stand. It combines with certain carbohydrates to produce compounds which are much less poisonous to the animal than is the free acid. Except in the later stages of poisoning, a strong solution of glucose, or "corn syrup," or molasses is said to be beneficial. Large quantities of milk have been administered with good results. The animal should always have as much fresh air as possible.

California False Hellebore (Veratrum californicum). Lily Family.-Most mountaineers know this plant by the erroneous name of "skunk cabbage." It is a coarse perennial with broad sessile leaves and grows in moist places in the mountain districts. Sheep sometimes browse on the foliage with impunity and there is much doubt as to the conditions under which the plant is poisonous. Symptoms of 
hellebore poisoning include salivation, burning in the throat, weak pulse, and labored respiration. Stimulants, tannic acid, and permanganate of potash have been recommended. The liberal use of lard and soda has sometimes proved effective in overcoming the ill effects of the weed.

Turkey Mullein (Eremocarpus setigerus). Spurge Family.Sheep are sumetimes killed in late summer and autumn by this weed. It is a low, grayish annual, forming leafy mats, and is densely stiffhairy throughout. When sheep eat the plants, as they sometimes do when better forage is not available, the branched hairs of the stems and leaves form into solid, indigestible balls in the alimentary tract. More than twenty of these balls, each the size of a hickory-nut, have been taken from the stomach of a single sheep. Belgian hares have also been killed by feeding on turkey mullein.

Western Choke-cherry (Prunus demissa). Rose Family.-This well-known shrub or small tree is common in the foothills and mounttains where its foliage is sometimes browsed upon with disastrous results. Care should be taken to see that animals driven across territory where choke-cherry grows are supplied with other feed. A simple expedient when several bands are to be taken to the same feeding ground is to route them by different trails so that each band will be supplied with harmless forage and not tempted to eat choke-cherry leaves. The poisonous principle is hydrocyanic (prussic) acid, which exerts a depressing action on the heart. Poisoned animals should be given a stimulant, for example alcohol, atropine, or inhalations of ammonia. Lard helps to prevent absorption of the poison.

Poison Hemlock (Conium maculatum). Parsley Family.-The flowers and fruit of poison hemlock resemble those of water hemlock but the tall stems grow from taproots and the leaves are much more finely dissected. The plant grows almost throughout the state but is quite generally avoided by stock, perhaps because. of its disagreeable odor.

Pale Laurel (Kalmia polifolia). Heath Family.-This low-spreading shrub with very smooth opposite leaves and lilac-purple flowers grows in moist places in the North Coast Ranges and Sierra Nevada. It is one of our most poisonous plants but fortunately grows in districts where there is but little stock-raising. Fat of any sort, if given in the early stages of poisoning, is beneficial and permanganate of potash will probably be found effective.

California Buckeye (Aesculus californica). Buckeye Family.The buckeye, or horse chestnut, is too well known to call for a des- 
cription. Its leaves and fruits are reputed to be poisonous to cattle, at least during certain seasons of the year. The fruit is washed and boiled or roasted by the Indians, who then eat it without ill effects.

Nightshade (Solanum species). Nightshade Family.-The nightshades are spreading herbs with alternate ovate stalked leaves and small clusters of white or blue flowers followed-by globose green or black berries. The amount of poison present varies greatly with growth. The herbage and green berries are perhaps always more or less poisonous but the ripe berries, especially if cooked, are harmless. The fruits of some varieties of nightshade are used in the making of pies and sauces but they are not picked until ripe. On the other hand, the green berries of the blue-flowered species have been known to kill children who had eaten them in play. Any of the domestic animals may be poisoned by nightshade. Practical experience has not yet indicated the best remedy for nightshade poisoning but in the case of man emetics or the stomach pump should be resorted to.

Thorn Apples (Datura meteloides, D. tatula, and D. stramonium). Nightshade Family.-CThese coarse, rank-smelling herbs are well known. Animals are not often poisoned but children sometimes eat the seeds, which are especially virulent. The recommended treatment, when human beings are poisoned, consists of the use of the stomach pump (or an emetic), heart stimulants and the application of external heat and artificial respiration if necessary.

Poison-oak (Rhus diversiloba). Sumach Family.-This is not a stock poisoning plant and is mentioned here only because of its popular interest. In some parts of the state it is a valuable shrub for browsing animals. (See further in Calif. Exp. Sta. Bull. No. 150).

The following list includes those plants, either native or widely introduced, which are either definitely known to be poisonous to stock or are under suspicion but which seldom if ever cause serious trouble in California. Plants which cause injury only through their mechanical action are not here included. All species in which the amount of toxicity is too slight to be of interest are likewise excluded.

Pteris aquilina Common Brake

Equisetum species Scouring Rush, Horse-tail

Taxus brevifolia

Typha latifolia Western Yew

Stipa vaseyi Cat-tail

Lolium temulentum Sleepy-grass Agrostemma githago Darnel Corn Cockle 


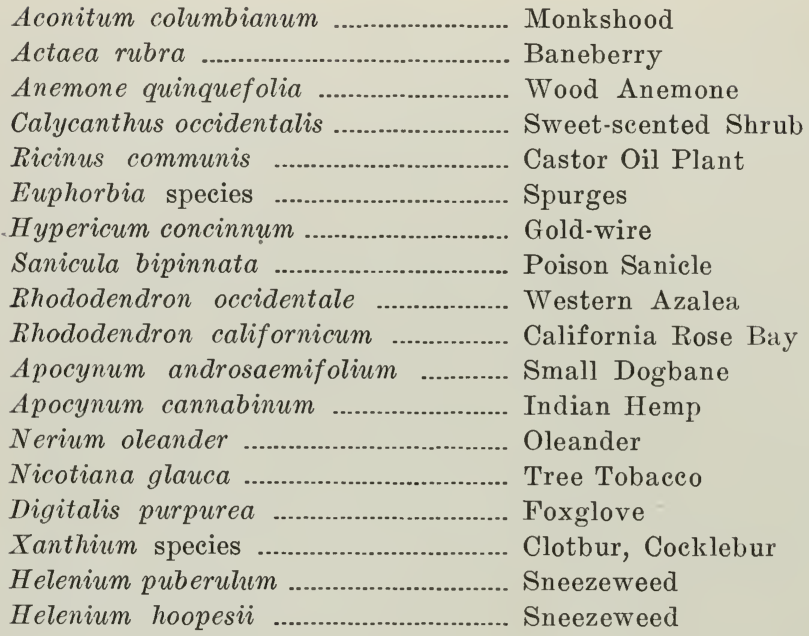

Death Camas (Zygadenus venenosus) ................................................................. 227

Tall Mountain Larkspur (Delphinium glaucum) ................................................. 231

Narrow-leaf Milkweed (Asclepias mexicana) ...................................................... 233

Lupine (Lupinus leucophyllus) ......................................................................... 237

Loco-weed (Astragalus hornii) ........................................................................... 239

\section{ACKNOWLEDGMEN'T}

Grateful acknowledgment is hereby made for assistance received from the United States Department of Agriculture. During the preparation of this bulletin the authors have drawn freely upon the publications of that institution and more especially upon those of Dr. C. Dwight Marsh, Dr. Carl L. Alsberg, Mr. V. K. Chesnut, and Mr. A. B. Clawson. They have also had the pleasure of consulting personally with these specialists and also with Dr. R. H. True of the same department, and here desire to express their thanks and appreciation to all of these for their generous assistance. 


\section{REFERENCES TO THE LITERATURE}

The following titles have been selected from a long list as being of practical value to veterinarians and stockmen in California.

Chesnut, V. K. Some common poisonous plants. Yearbook, U. S. Dept. Agric. 1896, pp. 137-146.

Chesnut, V. K. Thirty poisonous plants of the United States. U. S. Dept. Agric. Farmers' Bull. No. 86, 1898. (Out of print)

Chesnut, V. K. Principal poisonous plants of the United States. U. S. Dept. Agric. Div. Bot. Bull. No. 20, 1898. (Out of print)

Chesnut, V. K. and Wilcox, E. V. The stock-poisoning plants of Montana. U. S. Dept. Agric. Div. Bot. Bull. No. 26, 1901. (Out of print)

Cinesnut, V. K. Preliminary catalogue of plants poisonous to stock. U. S. Dept. Agric. Bur. of Animal Industry Rept. for 1898, pp. 387-420.

Crawford, Albert C. Mountain laurel, a poisonous plant. U. S. Dept. Agric. Bur. of Plant Industry, Bull. No. 121, pp. 21-35, 1908. (Out of print)

Marsh, C. Dwight. The loco-weed disease. U. S. Dept. Agric. Farmers' Bull. No. 380, 1909.

Marsh, C. Dwight. The loco-weed disease of the plains. U. S. Dept. Agric.

Bur. of Animal Industry Bull. No. 112, 1909. (Out of print)

Marsh, C. Dwight. Stock poisoning due to the scarcity of food. U. S.

Dept. Agric. Farmers' Bull. No. 536, 1913.

Marsh, C. Dwight, Alsberg, C. L., and Black, O. F. The relation of barium to the loco-weed disease. U. S. Dept. Agric. Bur. of Plant Industry, Bull. No. 246, 1912. (Technical Bulletin of value chiefly to specialists)

Marsh, C. Dwight, Clawson, A. B., and Marsh, Hadleigh. Larkspur, or "Poison Weed." U. S. Dept. Agric. Farmers' Bull. No. 531, 1913.

Marsh, C. Dwight, Clawson, A. B., and Marsh, Hadleigh. Cicuta, or Water Hemlock. U. S. Dept. Agric. Bull. No. 69, 1914.

PAMmel, L. H. A manual of poisonous plants (with bibliography by Harriette S. Kellogg). Cedar Rapids, Ia., The Torch Press, 1911.

Peters, A. T., Slade, H. B., and Avery, Samuel. Poisoning of cattle by common sorghum and kafir corn. Nebraska Exp. Sta., Bull. No. 77, 1903.

Slade, H. B. Some conditions of stock poisoning in Idaho. Idaho Exp. Sta., Bull. No. 37, 1903, pp. 159-190. 


\section{REPORTS}

1897. Resistant Vines, their Selection, Adaptation, and Grafting. Appendix to Viticultural Report for 1896.

1902. Report of the Agricultural Experiment Station for 1898-1901.

1903. Report of the Agricultural Experiment Station for 1901-03.

1904. Twenty-second Report of the Agricultural Experiment Station for 1903-04.

1914. Report of the College of Agriculture and the Agricultural Experiment Station, July, 1913-June, 1914.

\section{BULLETINS}

No.

116. The California Vine Hopper.

168. Observations on Some Vine Diseases in Sonoma County.

169. Tolerance of the Sugar Beet for Alkali.

170. Studies in Grasshopper Control.

174. A New Wine-Cooling Machine.

177. A New Method of Making Dry Red Wine.

178. Mosquito Control.

182. Analysis of Paris Green and Lead Arsenate. Proposed Insecticide Law.

183. The California Tussock-moth.

184. Report of the Plant Pathologist to July 1, 1906.

185. Report of Progress in Cereal Investigations.

186. Odium of the Vine.

195. The California Grape Root-worm.

197. Grape Culture in California; Improved Methods of Wine-making; Yeast from California Grapes.

198. The Grape Leaf-Hopper.

203. Report of the Plant Pathologist to July 1, 1909

207. The Control of the Argentine Ant.
No.

208. The Late Blight of Celery.

211. How to Increase the Yield of Wheat in California.

212. California White Wheats

213. The Principles of Wine-making.

215. The House Fly in its Relation to Public Health.

216. A Progress Report upon Soil and Climatic Factors Influencing the Composition of Wheat.

224. The Production of the Lima Bean.

225. Tolerance of Eucalyptus for Alkali.

227. Grape Vinegar.

230. Enological Investigations.

234. Red Spiders and Mites of Citrus Trees.

240. Commercial Fertilizers.

241. Vine Pruning in California. Part I

242. Humus in California Soils.

243. The Intradermal Test for Tuber culosis in Cattle and Hogs.

244. Utilization of Waste Oranges.

245. Commercial Fertilizers.

246. Vine Pruning in California, Part II.

247. Irrigation and Measuring Devices.

\section{CIRCULARS}

No.

46. Suggestions for Garden Work in California Schools.

62. The School Garden in the Course of Study.

65. The California Insecticide Law.

68. The Prevention of $\mathrm{Hog}$ Cholera.

69. The Extermination of Morning-Glory.

70. Observation of the Status of Corn Growing in California.

75. A New Leakage Gauge.

76. Hot Room Callusing.

79. List of Insecticide Dealers.

80. Boys' and Girls' Clubs.

82. The Common Ground Squirrels of California.

83. Potato Growing Clubs.

84. Mushrooms and Toadstools.

87. Alfalfa.

88. Advantages to the Breeder in Testing his Pure-bred Cows for the Register of Merit.

91. Disinfection on the Farm.

92. Infectious Abortion and Sterility in Cows.

98. Plowing and Cultivating Soils in California.

100. Pruning Frosted Citrus Trees.

101. Codling Moth Control in the Sacra. mento Valley.

102. The Woolly Aphis.
No.

106. Directions for using Anti-Hog-Cholera Serum.

107. Spraying Walnut Trees for Blight and Aphis Control.

108. Grape Juice.

109. Community or Local Extension Work by the High School Agricultural Department.

110. Green Manuring in California.

111. The Use of Lime and Gypsum on California Soils.

112. The County Farm Adviser.

113. Announcement of Correspondence Courses in Agriculture.

114. Increasing the Duty of Water.

115. Grafting Vinifera Vineyards.

116. Silk Worm Experiments.

117. The Selection and Cost of a Small Pumping Plant.

118. The County Farm Bureau.

119. Winery Directions.

120. Potato Growing in the San Joaquin and Sacramento Deltas of California.

121. Some Things the Prospective Settler Should Know.

122. The Management of Strawberry Soils in Pajaro Valley.

123. Fundamental Principles of Co-opera tion in Agriculture. 